DOI: 10.19195/2353-8546.6.16

\author{
AURELIA KOTKIEWICZ* \\ Uniwersytet Pedagogiczny (Kraków, Polska)
}

\title{
Wspomnienia Nadieżdy Mandelsztam jako forma reprezentacji pamięci
}

\begin{abstract}
Nadezhda Mandelstam's Hope against Hope: A Memoir as a form of representation of memory. Nadezhda Mandelstam's Hope Against Hope: a Memoir must be regarded as one of the most important accounts of the gradual subjugation of Russian literature in Stalin's Soviet Union. The purpose of my article is to examine the literary devices employed by the author in her attempt to describe her traumatic experiences, as well as the strategies she uses in order to 'tame the past' at a more personal, generational, and historical plan (concerning such experiences as loneliness, entrapment, solitude, homelessness, suffering, fear, and death). Her memoir enables her to relieve the trauma caused by the tragic fate of her husband, the poet Osip Mandelstam, as well as to recreate the final years of his life and work. In a broader context, the book offers thoughts and insights into the moral state of humanity. Together with such novels as Vasily Grossman's Everything Flows..., Lydia Chukovskaya's Sofia Petrovna, and Anna Akhmatova's Requiem, Nadezhda Mandelstam's writings are a shattering account of life in a totalitarian regime, marked by an ideologically driven process of distorting and erasing memory. She identified creative process not only with the struggle to keep her husband's name alive but also with a moral obligation to bear witness to the inhumanity of her time.
\end{abstract}

Keywords: memory, totalitarianism, trauma, Memories, Nadezhda Mandelstam

Воспоминания Надежды Мандельштам как форма репрезентации памяти. Воспоминания Надежды Мандельштам - это одно из самых выдающихся свидетельств процесса порабощения русской литературы в период сталинского террора. Целью статьи является анализ механизмов репрезентации личного травматического опыта Надежды Мандельштам, а также применяемых стратегий осваивания прошлого в личном, общественном и историческом контекстах (одиночество, отчужденность, бездомность, страдание, страх, смерть). Рядом с такими произведениями как Все

* Adres do korespondencji: Katedra Literatury Rosyjskiej, ul. Studencka 5, 31-116 Kraków. E-mail: akotkiewicz@op.pl. 
течет... Василия Гроссмана, Софья Петровна Лидии Чуковской, Реквием Анны Ахматовой, Воспоминания Надежды Мандельштам являются потрясающей записью гибели русской интеллигенции, а также идеологически управляемого процесса искажения и стирания памяти о прошлом. Творческий процесс Надежда Мандельштам отождествляет с борьбой за память о поэте Осипе Мандельштаме, его поэтическом наследии, но также с моральной ответсвенностью дать свидетельство времени.

Ключевые слова: память, тоталитаризм, травма, Воспоминания, Надежда Мандельштам

Niezapisane istnieje mniej.

Z czasem w ogóle przestaje istnieć.

Mija wraz z pamięcią ${ }^{1}$.

Najważniejszym celem, który przyświecał Nadieżdie Mandelsztam przez wiele lat po śmierci Osipa Mandelsztama, jednego z najwybitniejszych poetów XX wieku, było zachowanie i ocalenie od zapomnienia jego spuścizny artystycznej. W eseju Mozart i Salieri (Mou,apm u Сальерu), będącym wnikliwą analizą geniuszu poetyckiego Mandelsztama i istoty jego twórczości, wdowa po poecie pisała:

Znaczenie mojego życia mogę określić w sposób następujący: byłam świadkiem poezji. W czasach próby niemota ogarniała raz tego, raz innego poetę. Jej przyczyny bywały różne. Przerażenie, lęk, chęć usprawiedliwienia tego, co dzieje się dokoła, a nawet życzliwe zainteresowanie wydarzeniami. Wszystko to mogło stać się przyczyną niemoty, czyli zatraty samego siebie [...] Źródłem ocalenia pozostała jedynie świadomość własnej słuszności poetyckiej, którą osiąga się w stanie pełnej jasności, pozwalającej poecie wszystko wybaczyć, wszystko poznać i robić swoje, nie oglądając się na nic. Żyć „pod włos” czasów i epoki².

Nadieżda Mandelsztam, sama żyjąc „pod włos” epoki i przez 16 lat dzieląc życie $\mathrm{z}$ poetą, zapisała się $\mathrm{w}$ pamięci potomnych jako osoba apodyktyczna, chimeryczna, przewrażliwiona, złośliwa, uparta i bezlitosna w oskarżeniach wysuwanych wobec potomnych ${ }^{3}$, a jednocześnie, podobnie jak Lidia Czukowska czy Anna Achmatowa, niekwestionowany autorytet moralny. Ów maksymalizm etyczny i bezkompromisowość memuarystki wynikał, jak można sądzić, z ogromu traumatycznych przeżyć, jakie stały się jej udziałem, z poczucia krzywdy i upokorzenia, żalu i bezsilności.

Wspomnienia są jednym z najwybitniejszych dwudziestowiecznych świadectw procesu zniewolenia literatury rosyjskiej w okresie terroru stalinowskiego. Obok takich powieści, jak Wszystko płynie... (Bce meчem...) Wasilija Grossmana, Sofia Pietrowna (Софья Петровна) Lidii Czukowskiej czy poematu Requiem Anny Achmatowej, proza Nadieżdy Mandelsztam to wstrząsający zapis losów, stanu umysłowego, wyborów moralnych inteligencji rosyjskiej w warunkach dyktatu totalitarnego oraz

${ }^{1}$ A. Tuszyńska, Singer. Pejzaże pamięci, Kraków 2010, s. 353.

2 N. Mandelsztam, Mozart i Salieri. III, tłum. R. Przybylski, „Zeszyty Literackie” 1993, nr 43, s. 105.

${ }^{3}$ Zob. Д. Быков, Апология затравленного человека. Надежда Мандельштам, [w:] idem, Советская литература, Москва 2015; J. Brodski, Na śmierć Nadieżdy Mandelsztam (1899-1980), tłum. E. Krasińska, [w:] N. Mandelsztam, Wspomnienia, tłum. J. Czech, Warszawa 2015. 
jej duchowej samozagłady ${ }^{4}$. Przede wszystkim jednak memuary są formą ponownego przeżycia osobistej tragedii, związanej z losem męża, próbą uporządkowania swojego życia i utrwalenia traumatycznych doświadczeń. Swoje pamiętniki Nadieżda Mandelsztam, „wdowa wzorowa”, jak nazwała ją Anna Achmatowa, lub, jak określił ją Josif Brodski, „wdowa po kulturze”, pisała w latach 60. ubiegłego wieku Skomplikowana i bolesna praca pamięci, wspominanie i odtwarzanie przeszłych wydarzeń, wynikające z potrzeby opłakania śmierci, poddane są procesowi powtórzenia, co pozwala autorce na nowo przepracować traumę, przeboleć i oswoić stratę bliskiej osoby.

Celem niniejszych rozważań jest analiza pamięciowego mechanizmu reprezentacji traumatycznych doświadczeń autorki Wspomnień oraz stosowanych przez nią strategii dawania świadectwa, oswajania przeszłości w wymiarze osobistym, pokoleniowym i historycznym przy założeniu, że proces pisania spełnia tu rolę katharsis. Dystans czasowy i świadomość skali terroru stalinowskiego lat 30. poszerza pole widzenia autorki, pozwalając jej na większy krytycyzm i ironię wobec siebie oraz poety. Takie wydarzenia jak areszt Mandelsztama, zesłanie i poniewierkę memuarystka umieszcza w kontekście społecznym i historycznym. Owa rzeczywistość pozatekstowa - społeczna, kulturowa, historyczna - wpisująca się w przeżycia wspólnotowe jest nieodłącznie związana z osobistym doświadczeniem osaczenia i skazania. Istotą wspomnień Nadieżdy Mandelsztam jest ścisły związek między przeszłością a teraźniejszością, między nieobecnym (nie jest znana dokładna data śmierci Osipa Mandelsztama i nie ma on nawet grobu) a uobecnieniem (zrekonstruowaniem w pamięci):

tamtej majowej nocy ${ }^{6}$ postawiłam sobie jeszcze jedno zadanie, dla niego żyłam i do dzisiaj żyję. Nie byłam w stanie odmienić losu O.M., ale tylko ja mogłam uratować tę część rękopisów, która ocalała, wiele przechowałam też w pamięci. Dla czegoś takiego warto było oszczędzać siły ${ }^{7}$.

Sensem życia staje się ratowanie wierszy poety, choć memuarystka zdaje sobie sprawę, że jedynym sposobem na ich przetrwanie w latach dyktatu stalinowskiego było powtarzanie, uczenie się ich na pamięć aż do czasu, kiedy mogłyby zostać oficjalnie wydane.

${ }^{4}$ A. Drawicz, Wolna literatura, [w:] Historia literatury rosyjskiej XX wieku, red. A. Drawicz, Warszawa 1997, s. 564.

${ }^{5}$ Wspomnienia (Воспоминания) zostały opublikowane w języku rosyjskim w Nowym Jorku w 1970 roku, później ukazała się ich angielska skrócona wersja Hope gainst Hope: A Memoir. W Rosji ujrzały światło dzienne dopiero w okresie pieriestrojki. Polski przekład autorstwa Andrzeja Drawicza pt. Nadzieja w beznadziejności. Wspomnienia pojawił się w 1976 roku, oficjalnie przedrukowano je w 1997 roku, zaś w 2015 roku wydano Wspomnienia w tłumaczeniu Jerzego Czecha.

${ }^{6}$ Po raz pierwszy Osip Mandelsztam został aresztowany w nocy z 13 na 14 maja 1934 roku. Drugie aresztowanie miało miejsce 1 maja 1938 roku.

${ }^{7}$ N. Mandelsztam, Wspomnienia, tłum. J. Czech, Warszawa 2015, s. 30. W dalszej części artykułu odwołuję się do tego wydania Wspomnień, podając w nawiasie stronę. 
W swojej autodokumentalnej prozie Nadieżda Mandelsztam zajmuje pozycję bezpośredniego świadka i jednocześnie obserwatora ostatnich lat życia i twórczości poety, jest depozytariuszką jego przeżyć, emocji, zmagań duchowych i cierpienia, z uwagą obserwuje proces powstawania poezji, który opiera się na tym, „że się w napięciu wychwytuje i ujawnia nie wiadomo skąd wysyłaną, ale już istniejącą, harmonijną i znaczeniową całość, która stopniowo przyobleka się w słowo" (s. 93) ${ }^{8}$. Jednocześnie autorka wspomnień sama znajduje się w sytuacji wykluczenia. Po pierwsze - jako żona nieprawomyślnego wobec władzy poety, niepublikowanego przez wiele lat i wymazywanego z pamięci kulturowej, po drugie - jako dysydentka, krytyk dyktatury stalinowskiej, nietolerowana przez władze i poddawana szykanom. Po wielu latach tułaczki po śmierci męża (Taszkient, Uljanowsk, Czyta) Nadieżda Mandelsztam dopiero w 1958 roku uzyskała zgodę na powrót do Moskwy.

Świadomość obcowania z wybitnym poetą i artystą słowa nie wyklucza bardziej zobiektywizowanego spojrzenia na niego. Autorka Wspomnień przyznaje, że Osip Mandelsztam był osobą nadto dumną, egocentryczną i nadwrażliwą. Wie jednak, że jego histeryczność, rozdrażnienie, zachowania psychotyczne, nasilające się zwłaszcza po powrocie z więzienia w 1934 roku $^{9}$, miały nie tylko podłoże charakterologiczne. Ich przyczyną było poczucie głębokiego osamotnienia, niemożność publikowania i wykluczenie społeczne, co stało się zresztą udziałem innych wybitnych twórców epoki, by wspomnieć Izaaka Babla, Michaiła Zoszczenkę czy Andrieja Płatonowa. Bezpardonowe ataki krytyków marksistowskich i nagonka na poetę w latach 30., po powrocie z podróży do Armenii, były bezpośrednio związane z odrzuceniem przez niego zasad nowej metody artystycznej, jaką stał się realizm socjalistyczny:

Я опять стою у этого распутья - konstatował Mandelsztam — меня не принимает советская действительность. [...] Я не могу так: „посмотрел и увидел”. Нельзя как бык на корову уставиться и писать. Описывать Господь может или судебный пристав. Я не писатель. Я не могу так ${ }^{10}$.

Poczucie wykluczenia z przestrzeni społecznej pogłębia się po napisaniu wiersza Żyjemy tu, nie czując pod stopami ziemi..., bezpośredniej przyczyny jego pierwszego aresztowania w 1934 roku. Mandelsztam staje się homo sacer, banitą, pariasem, człowiekiem wyłączonym ze wspólnoty na mocy prawa ${ }^{11}$. Tylko na krótki czas, jak się okazało, zaledwie na cztery lata (do powtórnego aresztowania w 1938 roku), na mocy decyzji Stalina: „изолировать, но сохранить” pozostawiono go przy życiu ${ }^{12}$. Owo wykluczenie, przebywanie na progu, między włączeniem i wy-

${ }^{8}$ W eseju Mozart i Salieri Nadieżda Mandelsztam pisze o podejmowanych przez Mandelsztama próbach racjonalnego wytłumaczenia procesów twórczych; N. Mandelsztam, op. cit., s. 97.

${ }^{9}$ Halucynacje słuchowe i wzrokowe, choroba oczu, bezsenność i myśli samobójcze, jakie nawiedzały poetę po wyjściu z więzienia, to reakcje na traumę; zob. C. Caruth, Doświadczenie niczyje: trauma i możliwość historii (Freud, Mojżesz i monoteizm), tłum. K. Bojarska, „Teksty Drugie” 2010, nr 6, s. $111-123$.

${ }^{10}$ Н. Струве, Осип Мандельштам, London 1990, s. 326.

${ }^{11}$ G. Agamben, Homo sacer. Suwerenna władza: nagie życie, thum. M. Salwa, Warszawa 2008.

12 Б. Сарнов, Последний творческий акт. Случай Мандельитама, Москва 2000, s. 9. 
łączeniem ze wspólnoty, szczególnie boleśnie odczuwane jest tuż po wyjściu poety $\mathrm{z}$ więzienia i w trakcie pobytu na zesłaniu w Woroneżu. W liście do Kornieja Czukowskiego z kwietnia 1937 roku Mandelsztam z rezygnacją konstatuje: „То, что со мной делают - дальше продолжаться не может. Ни у меня, ни у моей жены нет больше сил длит этот ужас. [...] Я поставлен в положение собаки, пса... Я тень. Меня нет. У меня есть только право умереть" 13.

Sytuacja wykluczenia społecznego, pozostawania poza porządkiem prawnym, staje się też udziałem autorki Wspomnień. Mandelsztamowie podejmują heroiczny wysiłek, walcząc o zdobycie jakiejkolwiek pracy, mieszkania, środków do życia. Ich tułaczka przypomina ucieczkę zaszczutych zwierząt w poszukiwaniu bezpiecznego schronienia. Stają się jednak, jako elementy obce i szkodliwe społecznie, niewidzialni w przestrzeni: żandarmi nie podają im ręki, tłum na stacji kolejowej z obojętnością patrzy, gdy pod konwojem wyruszają na zesłanie, od pierwszych chwil towarzyszy im świadomość, że są skazani. Świadomość bycia w sytuacji „pomiędzy”, spowodowanej wykluczeniem i napiętnowaniem, autorka memuarów metaforycznie określa jako wyraźną granicę, przegrodę dzielącą świat na skazanych i na tych, których jeszcze nie aresztowano, na przeszłość i teraźniejszość: „Między nami a tamtym światem powstała przegroda. Na razie szklana, przezroczysta, ale już nie do przejścia” (s. 60); „Nikt się nawet nie odwrócił, żeby na nas popatrzeć” (s. 75); „pierścień zaciskał się systematycznie" (s. 172).

Nadieżda Mandelsztam rekonstruuje w swoich zapiskach obrazy miast, w których przyszło im mieszkać: Moskwa wywołuje bolesne wspomnienia związane z pobytem poety w więzieniu na Łubiance. Choć stolica to miasto zakazane dla wykluczonych i Mandelsztam dożywotnio stracił prawo pobytu w niej, przyciąga oboje jak magnes. W ciągu trzech lat zesłania w Woroneżu, ponurym, wygłodzonym mieście, Mandelsztamowie pięciokrotnie zmieniali miejsce zamieszkania. Kolejne etapy tułaczki to Czerdyńsk, Małajarosławiec, Kalinin, Strunino, Sawiołowo, Samaticha. Sanatorium w Woroneżu okazało się ostatecznie więzieniem i pułapką. Obrazy tych miejsc układają się w swoistą "topografię doświadczenia" ${ }^{4}$, które staje się jednocześnie doświadczeniem egzystencji. Przestrzeń miast, miasteczek i wsi radzieckich jest dla Mandelsztamów przestrzenią wykluczenia, udręczenia i napiętnowania. Zamieszkuje ją zbiorowość cierpiących, samotnych i przerażonych jednostek.

Reakcją na stan wykluczenia jest lęk i przeczucie zbliżającej się śmierci, widoczne w wierszach poety Więc za chwałe tych dni (За гремучую доблесть...), Żyjeту tu, nіе сzијас род stopami ziеті... (Мы живем, под собою не чуя страны...), Twoje waskie ramiona spłyna krwia pod biczami... (Твоим узким плечам под

${ }^{13}$ Н. Струве, op. cit., s. 329. W liście do szwagra Jewgienija Chazina Mandelsztam napisał: „W Woroneżu jesteśmy całkowicie izolowani. Od 13 znajdziemy się bez środków do życia, to znaczy herbaty, chleba, kaszy, jajecznicy. Nie ma od kogo pożyczyć”; cyt. za: T. Klimowicz, Pożar serca, Wrocław 2005, s. 280.

14 J. Leociak, Doświadczenie graniczne. Studia o dwudziestowiecznych formach reprezentacji, Warszawa 2009, s. 24. 
бичами краснеть...). Ten lęk przed terrorem i unicestwieniem nieodłącznie wiąże się u Mandelsztama $\mathrm{z}$ atawistycznym, niemalże fizjologicznym pragnieniem stopienia się ze wspólnotą, nawet za cenę skrajnego upokorzenia. Owa masochistyczna potrzeba zjednoczenia się z tłumem (widoczna także u Władimira Majakowskiego, Jurija Oleszy czy Michaiła Zoszczenki) przejawia się w strofach wiersza:

Nie chcę wśród młodzieńców cieplarnianych/ Rozmieniać duszy ostatniej kopiejki,/ Jak do kołchozu indywidualny,/ Tak wchodzę w świat i ludzie są mi piękni.// Zrozum mnie nareszcie - / Ja muszę żyć, oddychać bolszewiejąc/ I tuż przed śmiercią wciąż piękniejąc,/ Pobyć tu i poigrać z ludźmi jeszcze ${ }^{15}$.

Nadieżda Mandelsztam takie przekonanie poety o silnej więzi z ludźmi tłumaczy jego akmeistyczną wiernością materii, „rzeczom ziemskim” (s. 339), a także poczuciem więzi z historią i kulturą.

Ostatnim aktem wiary w „remont zdrowia”, zmianę psychiki, próbą włączenia się do kolektywu i chóru głosów sławiących tyrana była słynna Oda (Oda). Jak twierdzi Nadieżda Mandelsztam, jej autor napisał ten utwór w stanie głębokiego kryzysu, „z pętlą na szyi” (s. 254), dokonując gwałtu na sobie jako poecie i człowieku. Autorka Wspomnień jest uczestnikiem rozgrywających się wydarzeń, ofiarą nieludzkiego systemu i obserwatorką przemian w życiu społeczno-kulturowym ówczesnej Rosji oraz polityki partii skierowanej ku realizacji najważniejszego celu: stworzenia nowego człowieka ${ }^{16}$. Z perspektywy osoby wyjętej spod prawa i skazanej na nieistnienie opisuje osobiste traumatyczne doświadczenia skrajnej rozpaczy, osaczenia, bezdomności, samotności i strachu, jakie stały się udziałem jej samej i męża.

Odwaga, upór, nadzieja na ocalenie spuścizny poetyckiej Mandelsztama uwarunkowały styl jej wspomnień. Memuarystka świadomie rezygnuje ze słownictwa heroicznego, patosu i monumentalizacji. Obdarzona doskonałą pamięcią i zdolnością analitycznego myślenia, jest bardzo konkretna i precyzyjna. Jako świadek historii i jednocześnie ocalona ukazuje tragiczne skutki kryzysu wartości etycznych, który doprowadził do zniszczenia osobowości człowieka, do aprobaty bezprawia i zła. Oskarżenie kieruje autorka przede wszystkim w stronę inteligencji rosyjskiej, która nie potrafiła obronić swojej niezależności i swoją biernością usankcjonowała istniejący porządek totalitarny.

Język Wspomnień oddaje wszechogarniającą przemoc, bezradność i obezwładniający wolę i myślenie strach, a jednocześnie jest przejawem niemożności wysłowienia się, przekazu doświadczenia przekraczającego ludzką miarę: kilkuletniej poniewierki, bezdomności, oczekiwania na areszt, deportację, śmierć. Ta bezdomność, jaka była udziałem samej Nadieżdy Mandelsztam po aresztowaniu męża, paradoksalnie stała się gwarantem przeżycia: „Przyszli po mnie do naszego ostatniego

15 O. Mandelsztam, Stance, [w:] idem, Poezje, tłum. S. Pollak, Kraków 1983, s. 421; w liście do B. Kuzina z 1938 roku Mandelsztam pisał: „Еще не знаю, что с собой делать. Как будто еще очень молод. Здесь должно произойти превращение энергии в другое качество. »Общественный ремонт здоровья «- значит, от меня чего-то доброго ждут, верят в меня"; Б. Сарнов, op. cit., s. 29.

16 J. Smaga, W walce o „nowego człowieka”, [w:] Rosja w 20 stuleciu, Kraków 2001, s. 104-110. 
pokoju w Kalininie, ale już się stamtąd wyniosłam... Zabrakło dla mnie pułapki, więc o mnie, bezdomnej, zapomnieli; dlatego przeżyłam i ocaliłam wiersze O.M.” (s. 169). W lapidarnym, okraszonym często ironią stylu memuarystka oddaje grozę wydarzeń: „długość kolejek wskazywała nam, na jakim świecie żyjemy” (s. 30); „po 1937 ludzie przestali się ze sobą spotykać” (s. 52); „ćwiczyliśmy się więc w języku ezopowym” (s. 56); „znajdowaliśmy się w stanie bliskim hipnotycznego snu” (s. 63); „nastała niemota, pojawiły się pierwsze symptomy letargu” (s. 64); „nikt nikomu nie ufał” (s. 51); „spotykając się, rozmawialiśmy szeptem i zerkali na ściany...” (s. 51).

Autorka Wspomnień opisuje stan odrealnienia trudnej do zaakceptowania rzeczywistości, diagnozuje proces jej fałszowania i wypierania ${ }^{17}$, związany ze strachem i poczuciem winy. Racjonalizacja lub milczenie były podstawowymi mechanizmami obronnymi i adaptacyjnymi: „o przykrych sprawach należało zapominać” (s. 407); „ludzie jak najwcześniej kładli się spać, byleby nie zapalać lampy” (s. 405). Ten stan najgłębszego straumatyzowania prowadził do osłabienia relacji z rzeczywistością, czego efektem było zobojętnienie ${ }^{18}$.

Dominantą leksykalną we Wspomnieniach jest słowo „strach” — atrybut rzeczywistości totalitarnej, fenomen socjologiczny i psychologiczny, wyraz powszechnego doświadczenia. To właśnie strach zmuszał do zaakceptowania rzeczywistości, mimo jej dwoistego charakteru. Dla wielu przejawiał się on w ciągłej walce z konkretną rzeczywistością i autorytetem partii, co w atmosferze oficjalnego optymizmu doprowadzało do popełniania zbrodni i jej akceptacji w imię wyższego celu ${ }^{19}$. Nadieżda Mandelsztam określiła po latach strach jako zjawisko głęboko wpływające na świadomość człowieka, izolujące społecznie, zrywające więzi rodzinne, towarzyskie i pokoleniowe: „Ludzie bali się każdego spotkania i każdej rozmowy” (s. 383); „strach przybierał u nas całkiem namacalną, społeczną postać" (s. 338); „jedni podejrzewali każdego o donosicielstwo, drudzy bali się, że sami zostaną wzięci za donosicieli” (s. 113).

Właśnie w sytuacji osłabienia stabilnych ram percepcji świata dochodziło do zerwania kontaktów z osobą wykluczoną i prześladowaną, do niezauważania zła i bierności wobec cudzego cierpienia, do blokady emocjonalnej wobec własnych i cudzych traumatycznych przeżyć.

Autorka przekazuje swoje indywidualne doświadczenie, umieszczając go w kontekście doświadczeń pokoleniowych, używając często formy „my”: „staliśmy się roz-

17 Sny są zapisem głęboko traumatycznych i wypartych treści: „Korytarze - olbrzymie, jakby kryte sufitem ulice, rzędy drzwi po obu stronach [...] Niekiedy okazywało się, że za tymi drzwiami odnajdywałam swoich zmarłych krewnych” (s. 166); „Tamtej nocy przyśniły mi się ikony. Niedobra wróżba" (s. 450). O treściach wypartych, pojawiających się w snach zob. И. Паперно, Сны террора (сон как источник для истории сталинизма), http://magazines.russ.ru/nlo/2012/116/p18.html (dostęp: 31.08.2016).

18 A. Burzyńska, M.P. Markowski, Teorie literatury XX wieku, Kraków 2007, s. 65. Trauma rozumiana jako uraz, wywołujący wstrząs w psychice człowieka to, zdaniem J. Lacana, „efekt zbliżenia się do Realnego, czyli tego, na co nie ma słów w języku [...]. Realne jest traumatycznym jądrem w ludzkiej psychice, osłabiającym relację z rzeczywistością".

19 O. Figes, Szepty. Życie w stalinowskiej Rosji, tłum. W. Jeżewski, Warszawa 2007, s. 161-162. 
chwiani psychicznie, odrobinę nienormalni. Może nie od razu chorzy, ale też nie całkiem w porządku - podejrzliwi, zakłamani, zagubieni, z wyraźnymi zahamowaniami w mowie i podejrzanym, infantylnym optymizmem” (s. 114); „sami pomagaliśmy - milczeniem lub aprobatą — silnej władzy zwiększać tę jej siłę..." (s. 123); „Zmiażdżeni przez system, w którego budowie, tak czy owak, uczestniczył każdy z nas, okazaliśmy się niezdolni nawet do biernego oporu" (s. 460). Lęk przed samotnością i izolacją społeczną tłumił wątpliwości, usypiał, zobojętniał, sprzyjał również kształtowaniu się postaw zachowawczych. Nadieżda Mandelsztam poddaje analizie rozpad postaw moralnych, jaki miał miejsce w okresie reżimu stalinowskiego i demoralizację społeczeństwa ${ }^{20}$, włączając do rosyjskiej świadomości społecznej trudną do zaakceptowania dla wielu wiedzę o mechanizmach niszczenia ludzkiej osobowości. Pisze więc o odbieraniu obywatelom podmiotowości za pomocą ograniczeń w zakresie wolności poruszania się, za pomocą wprowadzenia systemu paszportów wewnętrznych, reglamentowania żywności, obowiązku meldowania się, polityki zagęszczania przestrzeni mieszkalnej, donosach jako systemie kontroli społecznej.

Osobiste, uzewnętrznione w procesie wspominania świadectwo Nadieżdy Mandelsztam indywidualizuje jej doświadczenie, dekonstruując jednocześnie narrację narzucaną przez oficjalny dyskurs ideologiczny. Bolesna praca pamięci i powrotu do przeszłości, oparta na szczerości wobec siebie, jest, jak twierdzi autorka, powolnym procesem „sklejania się poszczególnych kawałków życia” (s. 267), który, jak sama podkreśla, rozpoczął się dopiero w roku 1956.

Proces pisania, utożsamiany przez memuarystykę z moralnym obowiązkiem dawania świadectwa nieludzkim czasom, ma głęboki terapeutyczny sens, broni przed utratą pamięci i włącza doświadczenie osobiste do doświadczenia społecznego ${ }^{21}$. Wspomnienia są świadectwem pamięci i wypełnienia poetyckiego testamentu Osipa Mandelsztama, który w jednym ze swoich ostatnich wierszy z 1937 roku napisał: „Bo są kobiety z ziemią spokrewnione/ I każdy krok ich — to rozgłośne łkanie./ Żegnać umarłych i witać wskrzeszonych,/ Gdy z grobu wstają - to ich powołanie"22.

${ }^{20}$ Michał Heller pisze, że Nadieżda Mandelsztam „Z sumiennością dziejopisa i wnikliwością psychologa, z siłą i rzetelnością prawdziwego mistrza pióra opisuje społeczeństwo, w którym [...] wychodzi z użycia mnóstwo słów i pojęć - takich, jak męstwo, honor, sumienie, wolność”; zob. M. Heller, Świat obozów koncentracyjnych a literatura sowiecka, tłum. M. Kaniowski, Paryż 1974, s. 300.

${ }^{21}$ O scaleniu pamięci biograficznej i pokoleniowej zob. J. Assmann, Pamięć kulturowa. Pismo, zapamiętywanie i polityczna tożsamość w cywilizacjach starożytnych, tłum. A. Kryczyńska-Pham, Warszawa 2008; oraz M. Halbwachs, Społeczne ramy pamięci, tłum. M. Król, Warszawa 2008.

22 O. Mandelsztam, Bezwiednie kłoniąc się..., [w:] O. Mandelsztam, Poezje, tłum. S. Barańczak, Kraków 1983, s. 557. 


\section{Bibliografia}

Agamben G., Homo sacer. Suwerenna władza: nagie życie, tłum. M. Salwa, Wydawnictwo Prószyński i S-ka, Warszawa 2008.

Assmann J., Pamięć kulturowa. Pismo, zapamiętywanie i polityczna tożsamość w cywilizacjach starożytnych, tłum. A. Kryczyńska-Pham, Wydawnictwo Uniwersytetu Warszawskiego, Warszawa 2008.

Brodski J., Na śmierć Nadieżdy Mandelsztam (1899-1980), [w:] N. Mandelsztam. Wspomnienia, tłum. E. Krasińska, Wydawnictwo Agora, Warszawa 2015.

Burzyńska A., Markowski M.P., Teorie literatury XX wieku, Wydawnictwo Znak, Kraków 2007.

Caruth C., Doświadczenie niczyje: trauma i możliwość historii (Freud, Mojżesz i monoteizm), tłum. K. Bojarska, „Teksty Drugie” 2010, nr 6, s. 111-123.

Drawicz A., Wolna literatura, [w:] Historia literatury rosyjskiej XX wieku, red. A. Drawicz, Wydawnictwo Naukowe PWN, Warszawa 1997, s. 537-585.

Figes O., Szepty. Życie w stalinowskiej Rosji, tłum. W. Jeżewski, Wydawnictwo Magnum, Warszawa 2007.

Halbwachs M., Społeczne ramy pamięci, tłum. M. Król, Wydawnictwo Naukowe PWN, Warszawa 2008.

Heller M., Świat obozów koncentracyjnych a literatura sowiecka, tłum. M. Kaniowski, Instytut Literacki, Paryż 1974.

Klimowicz T., Pożar serca, Wydawnictwo Uniwersytetu Wrocławskiego, Wrocław 2005.

Leociak J., Doświadczenie graniczne. Studia o dwudziestowiecznych formach reprezentacji, Wydawnictwo Instytutu Badań Literackich PAN, Warszawa 2009.

Mandelsztam N., Mozart i Salieri. III, tłum. R. Przybylski, „Zeszyty Literackie” 1993, nr 43, s. 96-108.

Mandelsztam N., Wspomnienia, tłum. J. Czech, Wydawnictwo Agora, Warszawa 2015.

Mandelsztam O., Poezje. Wybór, red., posłowie M. Leśniewska, Wydawnictwo Literackie, Kraków 1983. Smaga J., Rosja w 20 stuleciu, Wydawnictwo Znak, Kraków 2001.

Tuszyńska A., Singer. Pejzaże pamięci, Wydawnictwo Literackie, Kraków 2010.

Быков Д., Советская литература, ПРОЗАиК, Москва 2015.

Паперно И., Сны террора (сон как источник для истории сталинизма), 2012, http://magazines. russ.ru/nlo/2012/116/p18.html.

Сарнов Б., Последний творческий акт. Случай Мандельитама, Издательство Московского университета, Москва 2000.

Струве Н., Осип Мандельштам, Overseas Publications Interchange Ltd, London 1990.

Przyjęto do druku/Accepted for publication: 5.05.2017

Miscellanea Posttotalitariana Wratislaviensia 6/2017

(C) for this edition by CNS 